$\operatorname{cocos}(1997), 12,33$ - 38

Printed in Sri Lanka

\title{
THE SUITABILITY OF OPTIONAL MATERIAL AS A REPLACEMENT FOR COIR DUST IN RAISING COCONUT SEEDLINGS IN POLYBAGS
}

\author{
C K Bandaranayake, R R A Peries and L Perera
}

Coconut Research Institute, Lunuwila, Sri Lanka.

\begin{abstract}
Although coir dust is recommended in the current potting mixture for raising coconut seedlings in polybags, it is becoming a scarce resource even within the coconut triangle. Therefore it was considered imperative to test the suitability of other options available locally.

An experiment conducted at the Bandirippuwa Research Nursery of the Coconut Research Institute revealed that saw dust, paddy husk, decomposed straw and weed trash were similar in action to coir dust in the potting media, considering the growth parameters of seedlings. However, with due respect to practical considerations, saw dust was found to be the best alternative. If there is no labour shortage, partially decomposed straw and weed trash can be used. Paddy husk was found to be the least important.
\end{abstract}

\section{INTRODUCTION}

The system of raising coconut seedlings in polythene bags is now popular in Sri Lanka (Wuidart, 1981; Peries and Everard, 1991) due to its proven benefits to the grower. The limitation of land availability in the tradig tional coconut growing areas has resulted in the cultivation being extended to the non-traditional areas, especially in the Mahaweli region where irrigation facilities are now available. Unless seedlings are raised in close proximity to the planting sites, the cost of transport will increase. Hence, it is very important to establish seedling nurseries in places close to planting sites.

The general potting mixture for raising coconut seedlings in polybags is a 1:2:3 mixture of top soil, cow dung and coir dust (Peries and Everard, 1991). Availability of coir dust is a major constraint in the non-traditional coconut growing areas, specially in dry zone, where other materials such as 
saw dust, paddy husk, straw and weed trash are in abundance. Even within the coconut triangle, coir dust increases the cost of production of the polybagged seedlings because of its increasing demand in the export market (Anonymous, 1994). Therefore, the use of coir dust in the potting mixture might not be a feasible proposition in the future. The objective of the present study was to test the suitability of optional material as a replacement for coir dust in making a satisfactory potting mixture.

\section{MATERIALS AND METHODS}

A nursery trial was carried out at the Bandirippuwa Research Nursery of the Coconut Research Institute, Sri Lanka from June 1995 to February 1996. The seed nuts used in the study were Tall $x$ Tall (CRIC60) from the Isolated Seed Garden (ISG), Ambakelle. Seven hundred and fifty seed nuts (750) were laid in a conventional pre-nursery bed (Peries, 1984) for subsequent transplanting in polybags. The sprouted seed nuts with more or less similar height and germination time, were transplanted as a sample of 25 seed nuts per treatment and altogether 125 seednuts in 5 treatments. The different potting mixtures used are indicated in Table 1.

Table 1: Different potting media for polybags mixed in the proportion 1:2:3 parts of each constituent

\begin{tabular}{|c|l|}
\hline Treatment & \multicolumn{1}{|c|}{ Potting media } \\
\hline T1 & Top soil + Cow dung + Coir dust \\
T2 & Top soil + Cow dung + Saw dust \\
T3 & Top soil + Cow dung + Paddy husk \\
T4 & Top soil + Cow dung + Partially de \\
T5 & composed straw \\
& Top soil + Cow dung + Weed trash \\
\hline
\end{tabular}

The seedlings were kept at a spacing of $60 \times 60 \times 60 \mathrm{~cm}$ triangular in a Completely Randomized Design (CRD). Polybags were irrigated once in three days (beginning from the seventh day when there was no rain for a continuous spell of six days or more) throughout the experiment with similar amounts of water in order to keep the seedlings free from water deficit.

Days taken to germination and the height at transplanting were recorded as an initial set of data. Seedling height, girth at collar and number of fully opened leaves were recorded at 7 months after laying. At this time, 
weight of polybags with seedlings was also recorded. Seedlings were held by the collar just after removing the polybags to investigate the anchorage of roots on the different potting media. Then the potting media were rinsed out with a jet of tap water and the weight of roots was recorded.

Statistical analysis of data was carried out to compare treatment differences in the parameters recorded with adjustment through covariance analysis. Days taken to germination and initial seedling height at transplanting were used as the covariates.

\section{RESULTS AND DISCUSSION}

There were no significant treatment differences for any ot the parameters such as, seedling height, girth at collar and number of fully opened leaves (Table 2). The results indicate that the material viz. saw dust, paddy husk, partially decomposed straw and weed trash were similar in action to coir dust. Considering the weight of polybags with the seedlings, there were no significant differences between treatments but polybags with partially decomposed straw had a marginally higher weight than the other 4 treatments (Táble 3):

Table 2: Results of the Analyses of Variance tests for seedling height (Heignt), girth at collar (Girth) and number of fully opened leaves (Leaves) for the different potting media.

\begin{tabular}{|c|c|c|c|}
\hline Treatment & Height (cm) & Girth (cm) & Leaves \\
\hline $\mathrm{T} 1$ & 102.20 & 12.08 & 4.32 \\
\hline $\mathrm{T} 2$ & 96.59 & 12.06 & 4.73 \\
\hline T3 & 9.7.57 & 12.36 & 4.52 \\
\hline T4 & $97.33^{\circ}$ & 12.93 & 4.50 \\
\hline T5 & 96.29 & 12.83 & 4.38 \\
\hline $\operatorname{LSD}(p<0.05)$ & 6.17 & 2.33 & 0.88 \\
\hline Significance & NS & NS & NS \\
\hline
\end{tabular}


An important aspect is the anchorage of roots to different potting media Treatments with coir dust and saw dust had better anchorage than the other 3 treatments on visual observation and the normal mixture had the best holding ability on roots. Seedlings established in partially decomposed straw produced a higher root mass compared to those raised in saw dust or paddy husk (Table 3).

Table 3: Average weight of polybags and roots at 7 months age, of the 5 treatments.

\begin{tabular}{|l|c|l|}
\hline Treatment & $\begin{array}{l}\text { Average weight of } \\
\text { Polybags (kg) }\end{array}$ & Roots (g) \\
\hline T1 & 10.730 & $109 \mathrm{ab}$ \\
T2 & 10.432 & $77.8 \mathrm{bc}$ \\
T3 & 10.480 & $49.4 \mathrm{c}$ \\
T4 & 11.440 & $122.4 \mathrm{a}$ \\
T5 & 10.430 & $114.8 \mathrm{ab}$ \\
LSD (P<0.05) & 1.0073 & 39.216 \\
& & $* *$ \\
Significance & NS & $*$ \\
\hline
\end{tabular}

(Values denoted by same letters are not significantly different)

Another important consideration is the refilling of polybags with the potting mixture with time. In this trial, refilling had to be done only in the case of straw and weed trash due to their higher rate of decomposition and the elastic nature of the material. Allison and Klein (1961) observed that the decomposition rate of saw dust in soil was very low. Similarly it would appear that coir dust and paddy husk which also contain a high level of hemicellulose have very low rate of decomposition. Refilling the bags as decomposition continues with time would lead to additional expenditure and hence would not be beneficial. Actually, it may result in an additional labour cost to the farmer for refilling of polybags

With respect to the efficacy of each mixture (Table 4), the best one is the normal potting mixture (Top soil, Cowdung, Coir dust) that is used at present in Sri Lanka. Polybags with coir dust mixture have a convenient weight and is easy to transport. The seedlings in coir dust mixture have suf- 
ficient root growth, specially feeder roots to absorb moisture and also for better anchorage to the media. It would not decompose rapidly and also has good authentic nature when pressed.

Table 4: Efficacy of each material as a part of polybag mixture in place of coir dust.

\begin{tabular}{|l|l|l|l|l|}
\hline Treatment & $\begin{array}{l}\text { Seedling } \\
\text { Vigour }\end{array}$ & Root Growth & Anchorage & Refilling \\
\hline T1 (Coir dust) & Good & Better & Best & Not necessary \\
T2 (Saw dust) & Good & Good & Better & Not necessary \\
T3 (Paddy husk) & Good & Poor & Poor & Not necessary \\
T4 (Straw) & Good & Best & Poor & Necessary \\
T5 (Weed trash) & Good & Better & Poor & Necessary \\
\hline
\end{tabular}

The weight of roots of seedlings in saw dust mixture was somewhat low and although they developed a sufficient amount of primary roots, the feeder roots were few. This would not be a problem for anchorage because saw dust has the ability to stack with top soil \& cowdung. The roots of seedlings in paddy husk mixture had very lose conglomeration due to poor piling ability of paddy husk and the least root growth compared to other treatments. Performance of partially decomposed straw and weed trash was almost similar when used as an optional material for coir dust. Seedlings in these media had well developed root systems but both had to be refilled because of their higher decomposition rates and the elastic nature of the material.

\section{CONCLUSION}

The study indicated that saw dust, paddy husk, partially decomposed straw and weed trash were similar in action to coir dust, considering the final seedling quality. Therefore, saw dust, paddy husk, partially decomposed straw and weed trash could be considered as options to replace coir dust in raising polybagged coconut seedlings.

However, considering factors such as, weight of roots, root anchorage and refilling of material during seedling growth, coir dust would appear to be the best. Among the optional materials tested; saw dust was the favourable alternative to coir dust. 
Although partially decomposed straw and weed trash were similar to coir dust in their effect on seedling quality, they increase the cost of production of polybagged seedlings because of the additional labour cost for refilling the material.

Paddy husk was found to be the least effective of the materials tested due to poor root growth and anchorage.

\section{REFERENCES}

Allison, F.E. and Klein, C.J.(1961). Comparative rates of decomposition in soil of wood and bark particles of several soft wood species. Soil Sci. Soc. Ameri. Proc. 25: 193-196.

Anonymous(1994). Export of coconut products - Comparative statistics. Coco Market Focus 9: 15-16.

Peries, R.R.A.(1984). Some observations on the pre-nursery system for rais ing coconut seedlings. Cocos 2: 10-17.

Peries, R.R.A. and Everard, J.M.D.T.(1991). River sand as an alternative to top soil for raising coconut seedlings in polybags. Cocos 9: 40-46.

Wuidart, W.(1981). Production of coconut planting material - The polybag nursery. Oleagineux 36: 367-373. 